\title{
PERUBAHAN PARADIGMA PROSES PEMBELAJARAN DALAM MEMBERIKAN LAYANAN PROFESIONAL BERBASIS KARAKTER
}

\author{
Prof. Dr, Festiyed, MS *) \\ Jurusan Fisika FMIPA UNP Padang \\ Hp.08126742403 dan E-mail festiyed@ymail.com
}

\section{PENDAHULUAN}

Kemajuan teknologi komunikasi dan informasi yang berkembang begitu pesat pada era globalisasi, membawa perubahan yang sangat radikal. Perubahan itu telah berdampak pada setiap aspek kehidupan, termasuk pada system pendidikan dan pembelajaran. Dampak dari perubahan yang luar biasa itu terbentuknya suatu 'kumonitas global', dimana komunitas global itu ternyata datang lebih cepat dari yang diperhitungkan: revolusi informasi telah menghadirkan dunia baru yang benarbenar hyper-reality.

Akibat dari perubahan yang begitu cepat, manusia tidak bisa lagi hanya bergantung pada seperangkat nilai, keyakinan, dan pola aktivitas social yang konstan. Manusia dipaksa secara berkelanjutan untuk menilai kembali posisi sehubungan dengan faktor-faktor tersebut dalam rangka membangun sebuah konstruksi social-personal. Jika masyarakat mampu bertahan dalam menghadapi tantangan perubahan di dalam dunia pengetahuan, teknologi, komunikasi serta konstruksi social budaya ini, maka kita harus mengembangkan proses-proses baru untuk menghadapi masalah-masalah baru ini. Kita tidak dapat lagi bergantung pada jawaban-jawaban masa lalu karena jawaban-jawaban tersebut begitu cepatnya tidak berlaku seiring dengan perubahan yang terjadi. Pengetahuan, metode-metode, dan keterampilan-keterampilan menjadi suatu hal yang ketinggalan zaman.

Degeng (1998) menyatakan bahwa kita telah memasuki era kesemrawutan. Era yang datangnya begitu cepat dan tak seorang pun mampu menolaknya. Pada era kesemrawutan ini tidak dapat dijawab dengan paradigma keteraturan, kepastian, dan ketertiban. Era kesemrawutan harus dijawab dengan paradigma kesemrawutan. Era kesemrawutan dilandasi oleh teori dan konsep konstruktivistik; suatu teori

\footnotetext{
${ }^{*}$ Dosen Jurusan Fisika FMIPA Universitas Negeri Padang, disampaikan pada semunar nasional MIPA dan PMIPA IAIN Suthan Thaha Saifuddin Jambi 18-20 Oktober 2013
} 
pembelajaran yang kini banyak dianut di kalangan pendidikan di AS. Unsur terpenting dalam konstruktivistik adalah kebebasan dan keberagaman. Kebebasan yang dimaksud ialah kebebasan untuk melakukan pilihan-pilihan sesuai dengan apa yang mampu dan mau dilakukan oleh peserta didik. Keberagaman yang dimaksud adalah peserta didik menyadari bahwa individunya berbeda dengan orang/kelompok lain, dan orang/kelompok lain berbeda dengan individunya.

Alternatif pendekatan pembelajaran bagi Indonesia yang sedang menempatkan reformasi sebagai wacana kehidupan berbangsa dan bernegara, bukan hanya di bidang pendidikan, melainkan juga di segala bidang. Selama ini, wacana kita adalah behavioristik yang berorientasi pada penyeragaman yang pada akhirnya membentuk manusia Indonesia yang sangat sulit menghargai perbedaan. Perilaku yang berbeda lebih dilihat sebagai kesalahan yang harus dihukum. Perilaku manusia Indonesia selama ini sudah terjangkit virus kesamaan, virus keteraturan, dan lebih jauh virus inilah yang mengendalikan perilaku kita dalam berbangsa dan bernegara.

Longworth (1999) meringkas fenomena ini dengan menyatakan: 'Kita perlu mengubah focus kita dari apa yang perlu dipelajari menjadi bagaimana caranya untuk mempelajari. Perubahan tersebut adalah perubahan dari isi menjadi proses. Belajar bagaimana cara belajar untuk mempelajari sesuatu menjadi suatu hal yang lebih penting daripada fakta-fakta dan konsep-konsep yang dipelajari itu sendiri'.

Oleh karena itu, pendidikan harus mempersiapkan para individu untuk siap hidup dalam sebuah dunia di mana masalah-masalah muncul jauh lebih cepat daripada jawaban dari masalah tersebut, di mana ketidakpastian dan ambiguitas dari perubahan dapat dihadapi secara terbuka, setiap individu harus memiliki keterampilan-keterampilan yang diperlukannya secara berkelanjutan menyesuaikan interaksi dengan sebuah dunia yang terus berubah, dan di mana setiap kita menjadi pemberi arti dari keberadaan kita. Beare \& Slaughter (1993) menagaskan, 'Hal ini tidak hanya berarti teknik-teknik baru dalam pendidikan, tetapi juga tujuan baru. Tujuan pendidikan haruslah untuk mengembangkan suatu masyarakat di mana orang-orang dapat hidup secara lebih nyaman dengan adanya perubahan daripada dengan adanya kepastian. Dalam dunia yang akan datang, kemampuan untuk menghadapi hal-hal baru secara tepat lebih penting daripada kemampuan untuk 
mengetahui dan mengulangi hal-hal lama. Untuk ini diperlukan cara berfikir kreatif, kritis, efektif dan inovatif.

Keadaan aktif dan menyenangkan tidaklah cukup jika proses pembelajaran tidak efektif, yaitu tidak menghasilkan apa yang harus dikuasai siswa setelah proses pembelajaran berlangsung, sebab pembelajaran memiliki sejumlah tujuan pembelajaran yang harus dicapai. Jika pembelajaran hanya aktif dan menyenangkan tetapi tidak efektif, maka pembelajaran tersebut tak ubahnya seperti bermain biasa.

Sedangkan inovatif suka merekonstruksi masalah, dan kemampuan menggunakan gagasan-gagasan atau ide-ide yang dilandasi oleh fakta dan informasi yang akurat dalam memecahkan atau mengatasi suatu masalah, dengan demikian kreativitas dalam pengertian kemampuan hanya mencakup dimensi kognitif. Ciri-ciri kreativitas tersebut belum sepenuhnya menjadi tolok ukur seseorang dapat disebut kreatif. Ciri lain yang harus dikembangkan yaitu ciri afektif menyangkut sikap dan perasaan seseorang, antara lain motivasi untuk berbuat sesuatu.

Berfikir kreatif dapat di defenisikan kedalam empat dimensi: berfokus pada pribadi, proses, dorongan dan produk. Kreatif berfokus pada pribadi muncul dari keunikan keseluruhan kepribadian dalam interaksi dengan lingkungannya. Kreatif yang berfokus pada dimensi proses mencerminkankelancaran, keluwesan, dan orisinal dalamberfikir, serta kemampuan untuk mengelaborasi (mengembangkan, memperkaya, memperinci) suati gagasan. Kreatif dalam dimensi dorongan internal diri sendiri berupa keinginan dan hasrat untuk mencipta atau bersibuk diri secara kreatif, maupun eksternal dari lingkungan sosial dan psikologis. Kreatif dalam dimensi produk berfokus pada apa yang dihasilkan oleh individu baik sesuatu yang baru/original atau sebuah elaborasi/penggabungan yang inovatif (berbeda /lebih baik).

Berfikir Kritis mencakup ketrampilan menafsirkan dan menilai pengamatan, informasi, argumentasi, penggunaan alasan yang logis, mencakup ketrampilan membandingkan, meklasifikasikan, melakukan pengurutan, menghubungkan sebab akibat, mendeskripsikan pola, membuat analogi, menyusun rangkaian, memberialasan secara deduktif dan induktif, peramalan, perencanaan, perumusan hipótesis, dan penyampaian kritik. Dan berfikir inovatif mengembangkandan 
mengimplementasikan gagasan-gagasan baru oleh orang dimana dalam jangka waktu tertentu melakukan transaksi-transaksi dengan orang lain dalam suatu tatanan organisasi.

Kebutuhan akan orientasi baru dalam pendidikan ini terasa begitu kuat dan nyata dalam berbagai bidang studi, baik dalam bidang studi eksakta maupun ilmu-ilmu lainnya. Para pendidik, praktisi pendidikan dan kita semua, mau tidak mau harus merespon perubahan yang terjadi dengan mengubah paradigma pendidikan. Untuk menjawab dan mengatasi perubahan yang terjadi secara terus-menerus, alternatif yang dapat digunakan adalah layanan profesional untuk menciptakan suasana pembelajaran aktif, inovatif, kreatif, efektif dan menyenengkan (PAIKEM) agar dapat menstimulus banyak kecerdasan (Multiple Intelligences) yang dimiliki peserta didik.

\section{Landasan Yurudis Pentingnya Merenovasi Proses Pembelajaran}

Seiring dengan berkembangnya cara berfikir dan teori pembelajaran modern, muncul pemikiran kritis untuk merenovasi proses pembelajaran yang berkualitas, humanis, dinamis dan konstruktif sebagai upaya untuk meningkatkan mutu pendidikan nasional. Upaya tersebut secara yuridis ditegaskan melalui beberapa kebijakan dan peraturan antara lain: UU No. 23 tahun 2002 tentang perlindungan anak, UU No. 20 tahun 2003 tentang sisdiknas, UU No. 14 tahun 2005 tentang guru dan dosen, PP No. 19 tahun 2005 tentang estándar nasional pendidikan, Kepmendiknas No. 129a tentang stándar pelayanan minimal bidang pendidikan. PP (Peraturan Pemerintah) nomor 8 tahun 2012 tentang KKNI (Kerangka kualifikasi nasional indonesia).

\section{Landasan Filosofis Perubahan Paradigma Proses Pembelajaran}

Pengembangan proses pembelajaran dapat ditinjau dari beberapa landasan filsafat pendidikan yang sesuia dengan era globalisasi adalah progresivesme, kontrutivisme dan humanisme.

\section{Progressivisme}

Progressivisme mempunyai konsep yang didasari oleh pengetahuan dan kepercayaan bahwa manusia itu mempunyai kemampuan- kemampuan yang wajar dan dapat menghadapi masalah yang menekan atau mengancam adanya manusia itu sendiri. Aliran Progressivisme mengakui dan berusaha mengembangkan asas 
Progressivisme dalam semua realitas, terutama dalam kehidupan adalah tetap survive terhadap semua tantangan hidup manusia, harus praktis dalam melihat segala sesuatu dari segi keagungannya. Berhubungan dengan itu Progressivisme kurang menyetujui adanya pendidikan yang bercorak otoriter, baik yang timbul pada zaman dahulu maupun pada zaman sekarang.

Pendidikan yang bercorak otoriter ini dapat diperkirakan mempunyai kesulitan untuk mencapai tujuan, karena kurang menghargai dan memberikan tempat semestinya kepada kemampuan- kemampuan tersebut dalam proses pendidikan. Pada hal semuanya itu ibaratkan motor penggerak manusia dalam usahanya untuk mengalami kemajuan atau progress.

Oleh karena itu kemajuan atau progress ini menjadi inti perhatian progressivisme, maka beberapa ilmu pengetahuan yang mampu menumbuhkan kemajuan dipandang oleh progressivisme merupakan bagian- bagian utama dari kebudayaan. Progresivisme dinamakan instrumentalisme, karena aliran ini beranggapan bahwa kemampuan intelegensi manusia sebagai alat untuk hidup, kesejahteraan, mengembangkan kepribadian manusia. Dinamakan eksperimentalisme, karena aliran tersebut menyadari dan mempraktekkan asa eksperimen yang merupakan untuk menguji kebenaran suatu teori. Sedangkan dinamakan environmetalisme karena aliran ini menganggap lingkungan hidup itu mempengaruhi pembinaan kepribadian.

Progresivisme yang lahir sekitar abad ke- 20 merupakan filsafat yang bermuara pada aliran filsafat pragmatisme yang diperkenalkan oleh William James (18421910) dan Jhon Dewey (1859-1952), yang menitikberatkan pada segi manfaat bagi hidup praktis.

Filsafat progresivisme dipengaruhi oleh ide- ide dasar filsafat pragmatisme dimana telah memberikan konsep dasar dengan asas yang utama yaitu manusia dalam hidupnya untuk tetap survive terhadap semua tantangan, harus pragmatis memandang sesuatu dari segi manfaatnya.

Disini kita bisa menganggap bahwa filsafat progresivismemerupakan The Liberal of Culture (kebebasan mutlak menuju kearah kebudayaan) maksudnya nilai- nilai yang dianut bersifat fleksibel terhadap perubahan, toleran dan terbuka sehingga 
menuntut untuk selalau maju bertindak secara konstruktif, inovatif dan reformatif, aktif serta dinamis. Untuk mencapai prubahan tersebut manusia harus memiliki pandangan hidup yang bertumpu pada sifat- sifat: fleksibel, curious (ingin mengetahui dan menyelidiki), toleran dan open minded.

Filsafat progressivisme telah memberikan kontribusi yang besar di dunia pendidikan, dimana telah meletakkan dasar- dasar kemerdekaan dan kebebasan kepada peserta didik. Anak didik diberikan kebebasan secara fisik maupun cara berfikir, guna mengembangkan bakat, kreatifitas dan kemampuan yang terpendam dalam dirinya tanpa terhambat oleh rintangan yang dibuat oleh orang lain. Berdasarkan pandangan di atas maka sangat jelas sekali bahwaa filsafat progressivisme bermaksud menjadikan anak didik yang memiliki kualitas dan terus maju sebagai generasi yang akan menjawab tantangan zaman peradaban baru.

\section{Konstruksivisme}

Konstruksivisme dalam perkembangannya tidak dapat dilepaskan denganpendapatnya Jen Piaget dan Vygotsky. Dalam pndangan konstruksivisme pengetahuan tumbuh dan berkembang melalui pengalaman (experience). Pemahaman akan berkembang semakin dalam dan kuat apabila selalu diuji oleh berbagai macam pengetahuan baru. Menurut Piaget manusia memiliki struktur pengetahuan dalam otaknya, seperti sebuah. kotak-kotak yang masing-masing mempunyai makna yang berbeda-beda. Pengalaman yang sama bagi seseorang akan dimaknai berbeda oleh masing-masing individu dan simpan dalam kotak yang berbeda. Setiap pengalaman yang baru akan dihubungkan dengan kotak-kotak atau struktur pengetahuan dalam otak manusia. Oleh karena itu, pada saat manusia belajar, sebenarnya telah terjadi dua proses darinya, yaitu proses organisasi informasi dan proses adaptasi.

Sedangkan menurut Vygotsky belajar adalah sebuah proses yang melibatkan dua elemen penting, yaitu: belajar merupakan proses secara biologi sebagai proses dasar, dan proses psikososial sebagai proses yang lebih tinggi dan essensinya berkaitan dengan lingkungan social budaya. Sehingga, menurut Vygotsky munculnya perilaku seseorang adalah intervening kedua elemen tersebut.

Konstruksivisme dalam pembelajaran mendasari tiga strategi pembelajaran, yaitu: 
a. Top-down processing. Dalam pembelajaran konstruksivisme peserta didik belajar dimulai dari masalah yang kompleks untuk dipecahkan, kemudian menghasilkan atau menemukan keterampilan yang dibutuhkan. Misalnya, peserta didik diminta untuk menulis kalimat- kalimat, kemudian dia akan belajar untuk membaca, belajar tentang tata bahasa kalimat- kalimat tersebut, dan kemudian bagaimana menulis titik dan komanya. Belajar dengan pendekatan top-down processing ini berbeda dengan pendekatan pembelajaran bottom up processing yang tradisional dimana keterampilan di bangun secara perlahan- lahan melalui keterampilan yang lebih kompleks.

b. Cooperative Learning. Cooperative Learning digunakan untuk proses pembelajaran, dimana peserta didik akan lebih mudah menemukan secara konprehenship konsep- konsep yang sulit. Cooperative Learning ini lebih menekankan pada lingkungan social belajar dan menjadikan kelompok belajar sebagai tempat untuk mendapatkan pengetahuan yang dimiliki oleh individu. Inilah kunci dari konsep- konsep dasar yang dikemukakan oleh Piaget dan Vygotsky.

\section{Humanisme}

Menurut faham humanisme, setiap peserta didik (anak didik) mempunyai seperangkat potensi yang dapat berkembang dan dikembangkan. Dalam pandangan humanisme, belajar bukan sekedar pengembangan kualitas kognitif saja, melainkan juga sebuah proses yang terjadi dalam diri individu yang melibatkan seluruh bagian atau domain yang ada. Domain- domain tersebut meliputi domain kognitif, afektif dan psikomotorik. Dengan kata lain, humanisme dalam pembelajaran lebih menekankan pentingnya emosi atau perasaan, komunikasi yang terbuka, dan nilai- nilai yang dimiliki oleh setiap peserta didik. Sehingga tujuan yang ingin dicapai dalam pembelajaran itu tidak hanya dalam domain kognitif saja, tetapi juga bagaimana peserta didik menjadi individu yang bertanggung jawab, penuh perhatian terhadap lingkungannya, mempunyai kedewasaan emosi dan spiritual.

Prinsip lain humanisme dalam pembelajaran adalah bahwa proses pembelajaran harus mengajarkan peserta didik, bagaimana belajar dan menilai kegunaan belajar itu bagi dirinya sendiri. Filsafat humanisme dalam proses pembelajaran telah melahirkan beberapa konsep yang berkaitan dengan pengembangan model yang 
memberikan kesempatan bagi peserta didik untuk membangun sendiri realitas bagi dirinya sendiri dan menekankan pada kemampuan peserta didik dalam domai kognitif, afektif, dan psikomotorik. Terdapat program pembelajaran yang dilandasi humanisme adalah "open schools atau open classroom", yang memiliki karakteristik sebagai berikut:

a. Peran guru dan peserta didik. Dalam open school guru berperan sebagai fasilitator yang membantu peserta didik secara untuk secara aktif membimbing diri mereka sendiri dalam belajar, dan peserta didik sendiri secara aktif memilih materi, metode dan langkah- langkah dalam pembelajaran.

b. Evaluasi diagnostic. Evaluasi belajar peserta didik tidak hanya didasarkan pada test yang dikerjakan oleh peserta didik, tetapi juga pada pengamatan terhadap hasil karya dan performma peserta didik dalam pembelajaran. Tujuan evaluasi dalam open school ini sebagai bimbingan pengajaran untuk memberikan feedback terhadap kinerja peserta didik dalam belajar dan bukan untuk menerapkan rangking peserta didik.

c. Materi. Pemberian materi yang berbeda- beda digunakan untuk memberikan stimulus bagi peserta didik agar dapat melakukan eksplorasi dalam belajar.

d. Pengajaran individual. Dalam open school system pembelajaran didasarkan pada kebutuhan- kebutuhan dan kemampuan individu peserta didik, sementara peserta didik belajar sesuai dengan kemampuan mereka sendiri.

e. Kelompok dengan berbagai tingkat usia. Kelompok yang dibentuk dalam proses pembelajaran terdiri dari peserta didik dengan berbagai tingkat usia, atau kelompok yang dibentuk tidak didasarkan pada tingkat, tetapi didasarkan pada aktivitas yang akan dilakukan.

f. Ruangan terbuka. Ruangan kelas tempat pembelajaran dirancang sedemikian rupa sehingga rungan dapat digunakan secara fleksibel untuk berbagai kegiatan pembelajaran. Dalam kegiatan open school, ruang pembelajaran tidaklah ruangan kelas yang selalu dibatasi oleh tembok dan berbagai perabotan, tetapi juga ruangan terbuka di luar kelas.

g. Team teaching. Sistem pembelajaran dapat direncanakan oleh dua atau lebih guru sebagai tim pengajar. Sehingga guru dapat merencanakan pengajaran bersama, berbagaai sumber belajar dan menggabungkan peserta didik. 


\section{Landasan Psikologis Perubahan Paradigma Proses Pembelajaran}

Beberapa tokoh pemikir aliran behavioristik yang dipandang melandasi teori PAIKEM adalah Ivan Petrovich Pavlov, Edward Lee Throndike dan Burhus Frederic Skinner

\section{Ivan Petrovich Pavlov}

Ivan Pavlov, ahli fisika berkebangsaan Rusia, pada akhir 1800-an dan awal 1900-an memelopori munculnya proses kondisining responden (respondent conditioning) dalam pembelajaran. Ivan Pavlov melakukan eksperimen terhadap seekor anjing. Pada saat seekor anjing diberi makanan dan lampu, keluarlah respon anjing itu berupa keluarnya air liur. Demikian juga jika dalam pemberian makanan tersebut disertai dengan bel, air liur anjing juga keluar. Setelah berkali- kali dilakukan hal serupa, maka pada saat hanya bel atau lampu yang diberikan, anjing tersebut juga mengeluarkan air liur. Makan yang diberikan oleh Pavlov disebut perangsang tak bersyarat (unconditional stimulus), sementara bel atau lampu yang menyertainya disebut sebagai perangsang bersyarat (conditional stimulus). Terhadap perangsang tak bersyarat yang disertai dengan perangsang bersyarat tersebut, anjing memberikan respon berupa keluarnya air liur (unconditional respons). Selanjutnya ketika perangsang bersyarat (bel/lampu) diberikan tanpa perangsang tak bersyarat (makanan) ternyata dapat menimbulkan respon yang sama, yaitu keluarnya air liur (conditional response). Karena itu teori Pavlov dikenal dengan response conditioning atau teori clasical conditioning.

Dari hasil eksperimen dengan menggunakn anjing tersebut. Pavlov akhirnya menemukan beberapa hukum pengkondisisan, yaitu; pemerolehan (acquisition), pemadaman (extinction), generalisasi (generalization), diskriminasi (descrimination) dan kondisioning tandingan (counter conditioning) (Davidof, 1981).

Pertama, pemerolehan adalah membuat pasangan stimulus netral dengan stimulus tak bersyarat berulang- ulang hingga muncul respons bersyarat, atau yang disebut acquisition training (latihan untuk memperoleh sesuatu). Para peneliti sering membuat stimulus netral bersamaan dengan stimulus bersyarat atau berbeda beberapa detik selisih waktu pemberiannya dan segera menghentikan secara serempak. Prosedur ini biasanya disebut dengan pengkondisian secara serempak (stimultaneus conditioning). Prosedur ini akan lebih sederhana dan efektif dalam 
melatih orang atau hewan. Memasangkan stimulus netral dan stimulus tak bersyarat selama latihan untuk memperoleh sesuatu akan berfungsi sebagai penguat atau reinforcement bagi respon bersyarat.

Kedua, Pemadaman (extinction). Setelah respons itu terbentuk, maka respon itu akan tetap ada selama masih diberikan ransangan bersyaratnya dan dipasangkan dengan ransangan tak bersyarat. Kalau rangsangan bersyarat diberikan untuk beberapa lama, maka respon bersyarat menurun dari pemunculannya dan akan semakin sering tak terlihat seperti penelitian sebelumnya. Pereistiwa itulah yang disebut dengan pemadaman (exticdtion). Beberapa respon bersyarat akan hilang secara perlahan- lahan atau hilang sama sekali untuk selamanya.

Ketiga, generalisasi dan diskriminasi. Ternyata respon bersyarat ini juga dapat dikenakan pada kejadian lain, namun situasinya yang mirip. Inilah yang dikenal dengan generalisasi stimulus atau generalisasi. Misalnya, pemuda yang mencintai seorang gadis, dan ia merasa bahagia jika bertemu dengan gadis tersebut. Pada saat ia mengetahui bahwa gadis yang dicintainya menyukai warna pink, maka ia akan merasa bahagia ketika menjumpai benda- benda apa saja yang berwarna pink. Bila suatu makhluk mengadakan generalisasi (menyamaratakan), maka ia juga akan dapat melakukan diskriminasi atau perbedaan. Diskriminasi yang dikondisikan ditimbulkan melalui penguatan dan pemadaman yang selektif.

Keempat, kondisioning tandingan (counter conditioning). Kondisioning ini merupakan salah satu bentuk khusus dari kondisioning responden. Pada kondisioning jenis ini, respon bersyarat yang khusus akan digantikan dengan respon bersyarat lain yang baru dan bertentangan, tidak saling cocok (incompatible) dengan respons bersyarat yang sebelumnya. Misalnya, respons bersyarat berupa perasaan tidak suka digantikan dengan perasaan suka, takut dengan berani, benci dengan cinta, dan lain sebagainya. Sehingga reaksi tersebut dapat disebut

\section{Edward Lee Throndike}

Eksperimen Pavlov telah memberikan inspirasi bagi para peneliti di Amerika, salah satunya adalah E. L. Thorondike. Melalui eksperimennya dengan seekor kucing, Throndike berkesimpulan bahwa belajar adalah proses interaksi antara stimulus (yang mungkin berupa pikiran, perasaan atau gerakan dan respons (yang 
juga bisa berbentuk pikiran, perasaan atau gerakan). Dari pengertian ini, wujud tingkah laku tersebut bisa saja dapat diamati ataupun tidak dapat diamati. Teori belajar Throndike juga disebut sebagai aliran "connectionism". Menurut Throndike belajar dapt dilakukan bila seseorang tidak tahu bagaimana harus memberikan respons atau sesuatu, kemungkinan akan ditemukan respons yang tepat berkaitan dengan masalah yang dihadapinya.

Throndike dalam eksperimennya, menemukan beberapa tentang belajar, sebagai berikut :

a. Hukum kesiapan (Law of Readiness). Jika seseorang siap melakukan sesuatu, ketika melakukannya maka ia puas. Sebaliknya bila ia tidak jadi melakukannya maka ia tidak puas.

b. Hukum Latihan (Law of Exercise). Jika respons terhadap stimulus diulangulang, maka akan memperkuat hubungan antara respons dan stimulus. Sebaliknya jika respon tidak digunakan, hubungan dengan stimulus semakin lemah.

c. Hukum Akibat (Law of effect). Jika hubungan antara respons dan stimulus menimbulkan kepuasan, maka tingkatan penguatannya semakin besar. Sebaliknya bila hubungan respons dan stimulus menimbulkan ketidakpuasan, maka tingkatan penguatannya semakin besar. Sebaliknya bila hubungan respons dan stimulus menimbulkan ketidakpuasan, maka tingkatan penguatan semakin lemah.

\section{Burhus Frederic Skinner}

Skinner dilahirkan di Pennsylvania Amerika Serikat 20 Mei 1904. Skinner mengembangkan teori conditioning dengan menggunakan tikus sebagai percobaan. Menurutnya, suatu respon sesungguhnya juga menghasilkan sejumlah konsekuensi yang nantinya akan mempengaruhi tingkah laku manusia. Kondisioning klasik Pavlov hanya menjelaskan bagaimana perilaku yang ada dipasangkan dengan rangsangan atau stimuli yang baru, tetapi tidak menjelaskan bagaimana perilaku operan baru dicapai. Pada dasarnya Skinner mendefenisikan belajar sebagai proses perubahan tingkah laku (Gleder, 1986). Perubahan perilaku yang dicapai sebagai 
hasil belajar tersebut melalui proses penguatan perilaku baru yang muncul, yang biasanya disebut dengan kondisioning operan (operant conditioning).

Secara konseptual, menurut Skinner (Woolfolk), perilaku dapat dianalogkan dengan sebuah sanwich, yang membawa dua pengaruh lingkungan terhadap perilaku. Pertama, disebut anteseden (peristiwa yang mendahului perilaku). Hubungan ini dapat ditunjukkan secara sederhana sebagai rangkaian antecedentsbehaviour- consequences, atau A-B-C. Sebuah rangkaian perilaku adalah sebuah proses dari qonsequences yang diberikan pada perilaku akan menjadi antecedents bagi munculnya perilaku, dan seterusnya. Penelitian dalam kondisioning operan menunjukkan bahwa perilaku operan dapat diubah dengan mengubah anteseden, konsekuen, atau antara keduanya. Operan adalah sejumlah menurut Reber (Syah, 2003) sejumlah perilaku atau respons yang membawa efek yang sama terhadap lingkungan dekat. Dalam operan perilaku dikendalikan oleh akibatnya, biasanya ini disertai dengan penguatan untuk perilaku yang muncul (arkinson, 1983).

Hasil eksperimen yang dilakukan oleh Skinner tersebut, menghasilkan prinsipprinsip belajar yang menghasilkan perubahan perilaku, yaitu :

Pertama, Reinforcement. Reinforcement didefenisikan sebagai sebuah konsekuen yang menguatkan tingkah laku (atau frekuensi tingkah laku). Keefektifan sebuah reinforment dalam proses belajar perlu ditunjukkan, karena kita tidak dapat menjadi reinforcer sampai terbukti bahwa konsekuen tersebut dapat menguatkan perilaku. Misalnya, permen pada umumnya dapat menjadi reinforce bagi perilaku anak kecil, tetapi ketika mereka beranjak dewasa permen bukan lagi suatu yang menyengkan, bahkan beberapa anak kecil juga tidak menyukai permen.

Secara umum reinforcement dapat dibedakan menjadi tiga;

a. Dari segi jenisnya, reinforcement dibagi menjadi dua kategori, yaitu; reinforcement primer dan reinforcement sekunder. Reinforcement primer adalah reinforcemen yang berupa kebutuhan pokok dasar manusia, seperti; makanan, air, keamanan, kehangatan, dan lain sebagainya. Sedangkan reinforcemen sekunder adalah reinforcemen yang diasosiasikan dengan reinforcemen primer. Misalnya, uang mungkin tidak bernilai bagi anak kecil sampai ia belajar bahwa uang itu dapat digunakan untuk membeli kue kesukaannya. Bagi siswa naik 
kelas mungkin mempunyai nilai yang kecil bagi dirinya, sampai mereka melihat kebahagiaan dan kebanggaan orang tuanya yang diwujudkan dalam bentuk pemberian hadiah ataupun ucapan selamat, pelukan dan ciuman akan keberhasilannya naik kelas. Pelukan, ciuman, ucapan selamat dan kebanggaan orang tua dapat merupakan reinforcemen primer, karena itu merupakan kebutuhan manusia.

b. Dari segi bentuknya. Reinforcement dibagi menjadi dua, yaitu reinforcement positif dan reinforcement negative. Reinforcement positif adalah konsekuen yang diberikan untuk menguatkan atau meningkatkan perilaku seperti hadiah, pujian, kelulusan dan sebagainya. Sedangkan reinforcement negative adalah menarik diri dari situasi yang tidak menyenangkan untuk menguatkan tingkah laku. Misalnya, guru yang membebaskan siswanya dari tugas membersihkan kamar mandi jika siswanya sudah menyelesaiakan tugasnya. Jika membersihkan kamar mandi merupakan tugas yang tidak menyenangkan, maka membebaskan seorang siswa dari tugas tersebut adalah suatu reinforce tingkah laku. Seringkali terjadi kesalahan interprestasi antara reinforcement negative dengan hukuman (punishment). Kata kunci kedua pengertian tadi adalah jika reinforcement baik positif atau negative selalu bertujuan untuk menguatkan tingkah laku, sedangkan punishment atau hukuman bertujuan untuk menurunkan atau memperlemah tingkah laku.

c. Waktu pemberian reinforcement. Keefektifan reinforcement dalam perilaku tergantung pada berbagai factor, salah satu adalah frekuensi atau jadwal pemberian reinforcement. Ada empat macam pemberian reinforcement, yaitu :

1) Fixed Ratio (FR) pemberian reinforcemen diberikan setelah sejumlah tingkah laku dilaksanakan. Misalnya, seorang guru mengatamakan; kalau kalian dapat menulis surat al-kafirun dengan cepat dan benar, maka kalian boleh pulang terlebih dahulu.

2) Variable Ratio (VR) adalah sejumlah perilaku yang dibutuhkan untuk berbagai macam reinforcemen. Jumlah perilaku yang dibutuhkan mungkin sangat bermacam-macam dan siswa tidak tahu perilaku mana yang akan direinforcemen. Misalnya, guru tidak hanya melihat apakah tugas dapat diselesaikan, tetapi juga melihat kemajuan-kemajuan yang diperoleh pada tahap-tahap menyelesaikan tugas tersebut. 
3) Fixed Interval (FI) yang diberikan ketika seseorang menunjukkan perilaku yang diinginkan pada waktu tertentu (misalnya tiap 30 menit sekali)

\section{Pentingnya Layanan Profesional}

Layanan professional merupakan suatu kegiatan atau urutan kegiatan yang terjadi dalam interaksi langsung antara seseorang dengan orang lain secara professional sehingga dapat memuaskan pihak yang dilayani. Dengan layanan ini diharapkan kegiatan pembelajaran dapat dapat berjalan dengan baik, sehingga proses pembelajaran menjadi kegiatan yang menyenangkan peserta didik. Hal ini disebabkan karena layanan yang diberikan mampu memenuhii keinginan atau kebutuhan peserta didik.

Secara umum "Pelayanan Profesional Kegiatan Pembelajaran" dirancang untuk memberikan arahan pada guru pada saat melaksanakan proses pembelajaran di depan kelas. Guru diharapkan dapat menyediakan pengalaman belajar yang beragam baik mental, fisik dan sosial. Guru juga mengelola tempat belajar, siswa, kegiatan pembelajaran, isi/materi, sumber belajar sedemikian rupa sehingga siswa aktif bertanya, mempertanyakan, dan mengemukakan gagasan. Belajar memang merupakan suatu proses aktif dari si pembelajar dalam membangun pengetahuannya, bukan proses pasif yang hanya menerima kucuran ceramah guru tentang pengetahuan. Sehingga, jika pembelajaran tidak memberikan kesempatan kepada siswa untuk berperan aktif, maka pembelajaran tersebut bertentangan dengan hakikat belajar. Peran aktif dari siswa sangat penting dalam rangka pembentukan generasi yang kreatif, yang mampu menghasilkan sesuatu untuk kepentingan dirinya dan orang lain. Kreatif juga dimaksudkan agar guru menciptakan kegiatan belajar yang beragam sehingga memenuhi berbagai tingkat kemampuan siswa. Menyenangkan adalah suasana belajar-mengajar yang menyenangkan sehingga siswa memusatkan perhatiannya secara penuh pada belajar sehingga waktu curah perhatiannya tinggi. Menurut hasil penelitian, tingginya waktu curah terbukti meningkatkan hasil belajar (Festiyed, 2008).

Layanan profesional untuk menciptakan suasana pembelajaran aktif, inovatif, kreatif dan menyenangkan apabila siswa terlibat dalam berbagai kegiatan yang mengembangkan pemahaman dan kemampuan mereka dengan penekanan pada belajar melalui berbuat. Pembelajaran akan menyenangkan jika 
pembelajaran memberikan perlakuan bervariasi sesuai dengan gaya dan kecerdasan yang dimiliki peserta didik, karena setiap peserta didik memiliki kecerdasan dan kemampuan berbeda dalam memahami sebuah mata pelajaran, sehingga berbeda pula pengalaman yang diperolehnya (Festiyed, 2008). Pentingnya perlakuan guru yang bervariasi dalam pembelajaran, diperkuat oleh pendapat Edgare Dale yang mengemukakan teori kerucut pengalaman, dalam teori ini keberhasilan belajar diukur dengan kadar pengalaman belajar yang diperoleh peserta didik tergantung perlakukannya dalam belajar, baik perlakukan guru atau aktivitas peserta didik ketika belajar. Kerucut pengalaman tersebut seperti gambar berikut:

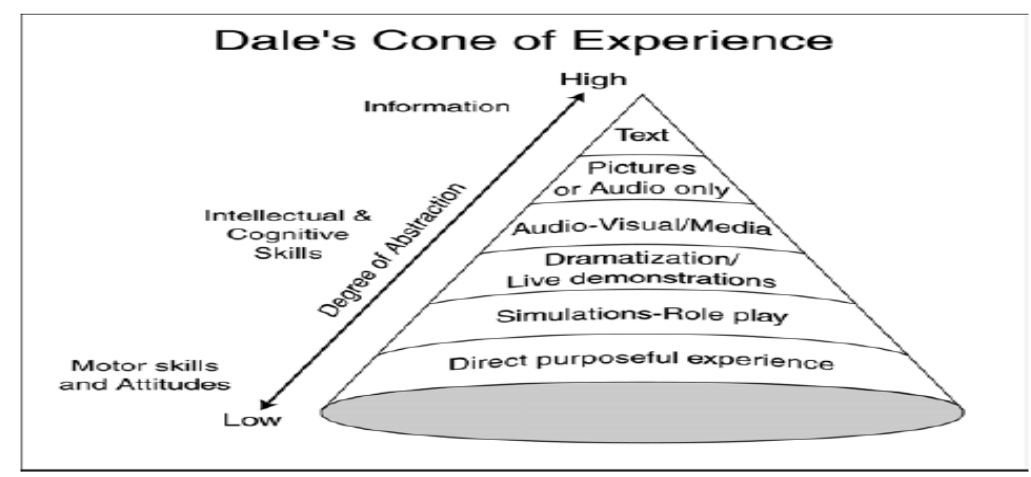

Gambar 1. Kerucut Pengalaman Edgare Dale

Gambar 1, memperlihatkan rentangan tingkat pengalaman dari yang bersifat langsung hingga ke pengalaman melalui simbol-simbol komunikasi, yang merentang dari yang bersifat kongkrit ke abstrak, dan tentunya memberikan implikasi tertentu terhadap pemilihan metode dan bahan pembelajaran. Dalam arti belajar bukan hanya membaca atau mendengar saja tapi lebih dari itu belajar merupakan satu kesatuan yang terintegrasi sehingga tercipta suatu proses belajar yang maksimal. Seseorang dapat memprogram dirinya dalam konteks belajar tersebut untuk dapat mengerti suatu ilmu baru dengan metode-metode khusus yang dimilikinya. Inilah yang membedakan kualitas belajar seorang yang satu dengan proses belajar orang lain. 
Seorang pendidik tidak boleh memaksakan peserta didiknya untuk memahami setiap pelajaran dengan pemahaman yang sama dan sempurna dengan satu takaran kecerdasan, sebab kecerdasan peserta didik dalam satu kelas berbeda-beda. Seorang pendidik harus mengakui dan menghargai bakat dan perbedaan kecerdasan peserta didiknya. Begitu juga pola pemikiran tradisional yang menekankan pada kemampuan logika dan bahasa dalam proses pembelajaran di kelas sudah waktunya diubah dengan kecerdasan majemuk yang pada dasarnya adalah sinergi dari kecerdasan otak (IQ), kecerdasan emosional (EQ) dan kecerdasan spiritual (SQ). Menurut Garnerd (1983;1993) Intellegence (Kecerdasan) adalah kemampuan untuk memecahkan persoalan dan menghasilkan produk dalam suatu setting yang bermacam-macam dan dalam situasi nyata

Peserta didik yang mempunyai taraf kecerdasan rendah atau di bawah normal sukar diharapkan berprestasi tinggi. Tetapi tidak ada jaminan bahwa dengan taraf kecerdasan tinggi seseorang secara otomatis akan sukses belajar di sekolah. Kecerdasan intelektual tidak hanya mencakup dua parameter tersebut, tetapi harus dilihat dari aspek kinetis, musical, visual-spatial,interpersonal, intrapersonal, dan naturalis (Kompas, 6 Agustus 2003: T.Amstrong, 2004). Jenisjenis kecerdasan intelektual tersebut dikenal dengan sebutan kecerdasan jamak (Multiple Intelligences) yang diperkenalkan oleh Howard Gardner pada tahun 1983.

Gardner mengatakan bahwa kita cenderung hanya menghargai orang-orang yang memang ahli di dalam kemampuan logika (matematika) dan bahasa. Kita harus memberikan perhatian yang seimbang terhadap orang-orang yang memiliki talenta (gift) di dalam kecerdasan yang lainnya seperti artis, arsitek, musikus, ahli alam, designer, penari, terapis, entrepreneurs, dan lain-lain. Sangat disayangkan bahwa saat ini banyak peserta didik yang memiliki talenta (gift), tidak mendapatkan reinforcement di sekolahnya. Banyak sekali peserta didik yang pada kenyataannya dianggap sebagai peserta didik yang "Learning Disabled" atau ADD (Attention Deficit Disorder), atau Underachiever, pada saat pola pemikiran mereka yang unik tidak dapat diakomodasi oleh sekolah. Pihak sekolah hanya menekankan pada kemampuan logika (matematika) dan bahasa.

Teori ini membantu kita lebih memahami mengapa gaya belajar pada masing-masing orang berbeda. Dan, kita pun bisa membayangkan kenapa respon 
terhadap suatu hal tidak ada yang serupa antara satu orang dengan orang yang lain. Jadi ada spektrum yang sangat luas dari sisi metode, media, strategi, dan lingkungan belajar yang dapat dikembangkan bagi siapa pun, karena semua peserta didik itu cerdas dan ada banyak cara untuk mengembangkan keunikan talentanya. Sebagai contoh, apakah Einstein akan sukses seperti itu bila dia masuk di Jurusan Biologi atau belajar main bola dan Musik jelas masalah fisikateoritis Einstein, Max Planc, Stephen Howking, Newton adalah jenius-jenius, tetapi bab olah-raga maka Zidane, Jordane, Maradona adalah jenius-jenius dilapangan, juga Mozart, Bach adalah jenius-jenius dimusik. Thomas A. Edison adalah jenius lain, demikian juga dengan para sutradara film, bagaimana mereka mampu membayangkan harus disyuting bagian ini, kemudian setelah itu, adegan ini, ini yang mesti keluar dengan pakaian jenis ini, latar suara ini, dan bahkan dialog seperti itu, ini adalah jenius-jenius bentuk lain. Disinilah Howard Gardner mengeluarkan teori baru dalam buku Frame of Mind, tentang Multiple Intelligences (Kecerdasan Majemuk), dimana dia mengatakan bahwa era baru sudah merubah dari Test IQ yang melulu hanya test tulis (dimana didominasi oleh kemampuan Matematika dan Bahasa), menjadi Multiple Intelligences. Ada delapan macam Multiple Intelligences.yang diungkapkan oleh Gardner (1983) yaitu:Teori Multiple Intelligences didasarkan pada pemikiran bahwa kemampuan intelektual yang diukur melalui tes $I Q$ sangatlah terbatas karena tes $I Q$ hanya menekan pada kemampuan logika (matematika) dan bahasa (Gardner, 2003). Padahal setiap orang mempunyai cara yang unik untuk menyelesaikan persoalan yang dihadapinya. Kecerdasan bukan hanya dilihat dari nilai yang diperoleh seseorang. Kecerdasan merupakan kemampuan yang dimiliki oleh seseorang untuk melihat suatu masalah, lalu menyelesaikan masalah tersebut atau membuat sesuatu yang dapat berguna bagi orang lain.

\section{Perubahan Paradigma Pengembangan Kurikulum Perguruan Tinggi mengacu Rumusan KKNI}

Kurikulum dapat dimaknai sebagai: suatu dokumen atau rencana tertulis mengenai kualitas pendidikan yang harus dimiliki oleh peserta didik melalui suatu pengalaman belajar. Pengertian ini mengandung arti bahwa kurikulum harus tertuang dalam satu atau beberapa dokumen atau rencana tertulis. Dokumen atau rencana tertulis itu berisikan pernyataan mengenai kuahtas yang harus dimiliki 
seorang peserta didik yang mengikuti kurikulum tersebut aspek lain dari makna kurikulum adalah pengalaman belajar. Pengalaman belajar di sini dimaksudkan adalah pengalaman belajar yang dialami oleh peserta didik seperti yang direncanakan dalam dokumen tertulis. Pengalaman belajar peserta didik tersebut adalah konsekuensi langsung dari dokumen tertulis yang dikembangkan oleh dosen/instruktur/pendidik. Dokumen tertulis berupa kegiatan nyata yang dikembangkan dosen ini dinamakan Rencana Perkuliahan/Satuan Pembelajaran. Pengalaman belajar ini memberikan dampak langsung terhadap hasil belajar mahasiswa. Oleh karena itu jika pengalaman belajar ini tidak sesuai dengan rencana tertulis maka hasil belajar yang diperoleh peserta didik tidak dapat dikatakan sebagai hasil dari kurikulum.

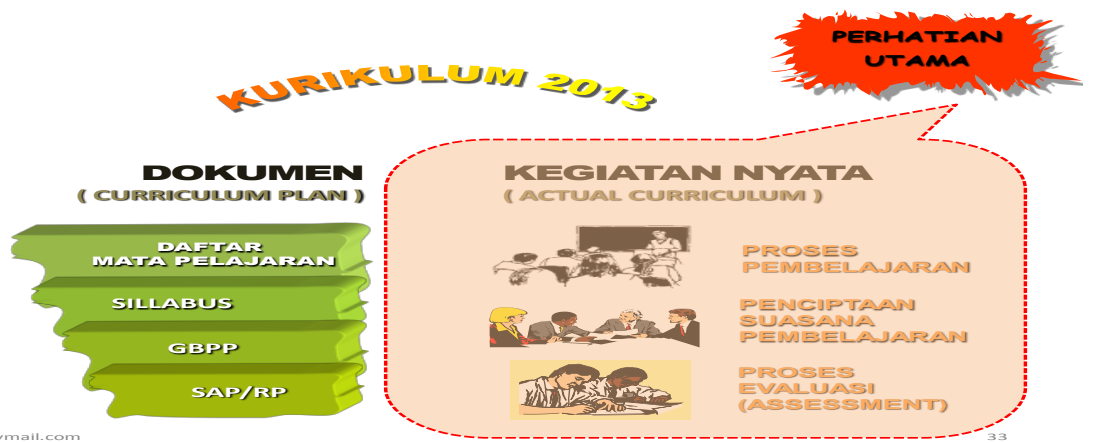

\section{Gambar 1 Perhatian Utama dalam Pengembangan Kurikulum (Endrotomo, 2010)}

Proses dalam pengembangan kurikulum didasari atas banyak faktor yang harus dipertimbangkan. Misalnya pertimbangan; (1) falsafah hidup bangsa, (2) harapan, kebutuhan, dan permintaan masyarakat akan produk pendidikan, (3) kesesuaian kurikulum dengan kondisi peserta didik, sebab pada dasarnya kurikulum adalah untuk peserta didik, (4) kemajuan ilmu pengetahuan dan teknologi serta seni yang tidak dapat dipungkiri, (5)perkembangan kebutuhan masyarakat pemangku kepentingan,(6)kecendrungan masa depan,(7) adanya KKNI

$\mathrm{KKNI}$, adalah kerangka penjenjangan kualifikasi kompetensi yang dapat menyandingkan, menyetarakan, dan mengintegrasikan antara bidang pendidikan dan bidang pelatihan kerja serta pengalaman kerja dalam rangka pemberian pengakuan kompetensi kerja sesuai dengan struktur pekerjaan di berbagai sektor. $\mathrm{KKNI}$ terdiri atas 9 (sembilan) jenjang kualifikasi, dimulai dari jenjang ke-1 sebagai 
jenjang terendah sampai dengan jenjang ke-9 sebagai jenjang tertinggi. Jenjang ke1 sampai dengan jenjang ke-3 dikelompokkan dalam jabatan operator; Jenjang ke-4 sampai dengan jenjang ke-6 dikelompokkan dalam jabatan teknisi atau analis; Jenjang ke-7 sampai dengan jenjang k-9 dikelompokkan dalam jabatan ahli.

Setiap jenjang kualifikasi pada KKNI memiliki kesetaraan dengan capaian pembelajaran yang dihasilkan melalui pendidikan, pelatihankerja atau pengalaman kerja. Capaian pembelajaran yang diperoleh melalui pendidikan ataupelatihan kerja dinyatakan dalam bentuk sertifikat. Sertifikat berbentuk ijazah dan sertifikat kompetensi. ljazah merupakan bentuk pengakuan atas capaian pembelajaran yang diperoleh melalui pendidikansedang sertifikat kompetensi merupakan bentuk pengakuan atas capaian pembelajaran yangdiperoleh melalui pendidikan atau pelatihan kerja.

Untuk semua jenjang pendidikan dibutuhkan rumusan "learning outcomes" (LO) lulusan prodi tertentu, yangsesuai dengan level KKNI nya, yang akan digunakan sebagai acuan bagiprogram studi sejenis di seluruh Indonesia.Rumusan tersebut merupakan pernyataan "kemampuan minimal" yangharus dimiliki oleh setiap lulusan program studi tersebut.

Pengembangan kurikulum yang mengacu rumusan KKNI memerlukan langkah dan strategi yang harus dikaji berdasarkan analisis yang cermat dan teliti. Analisis dilakukan melalui

a. Melakukan analisis SWOT, Tracer study, untuk menjabarkan profil lulusan

b. Merumuskan Kompetensi lulusan (Learning Outcomes) berdasarkan deskripsi KKNI

c. Pemilihan bahan kajian sesuai 5 elemen kompetensi untuk menyusun matakuliah

d. Membuat matrik keluasan, kedalaman dan kemampuan yg ingin dicapai dg bahan kajian

e. Membuat konsep integrasi bahan kajian untuk mata kuliah dan besarnya SKS

f. Membuat konsep struktur kurikulum

g. Pembuatan perangkat pembelajaran (silabus, rencana pembelajaran, Tugas, Asesmen, Modul Praktikum, Handout, Diktat, Buku ajar, Buku, 

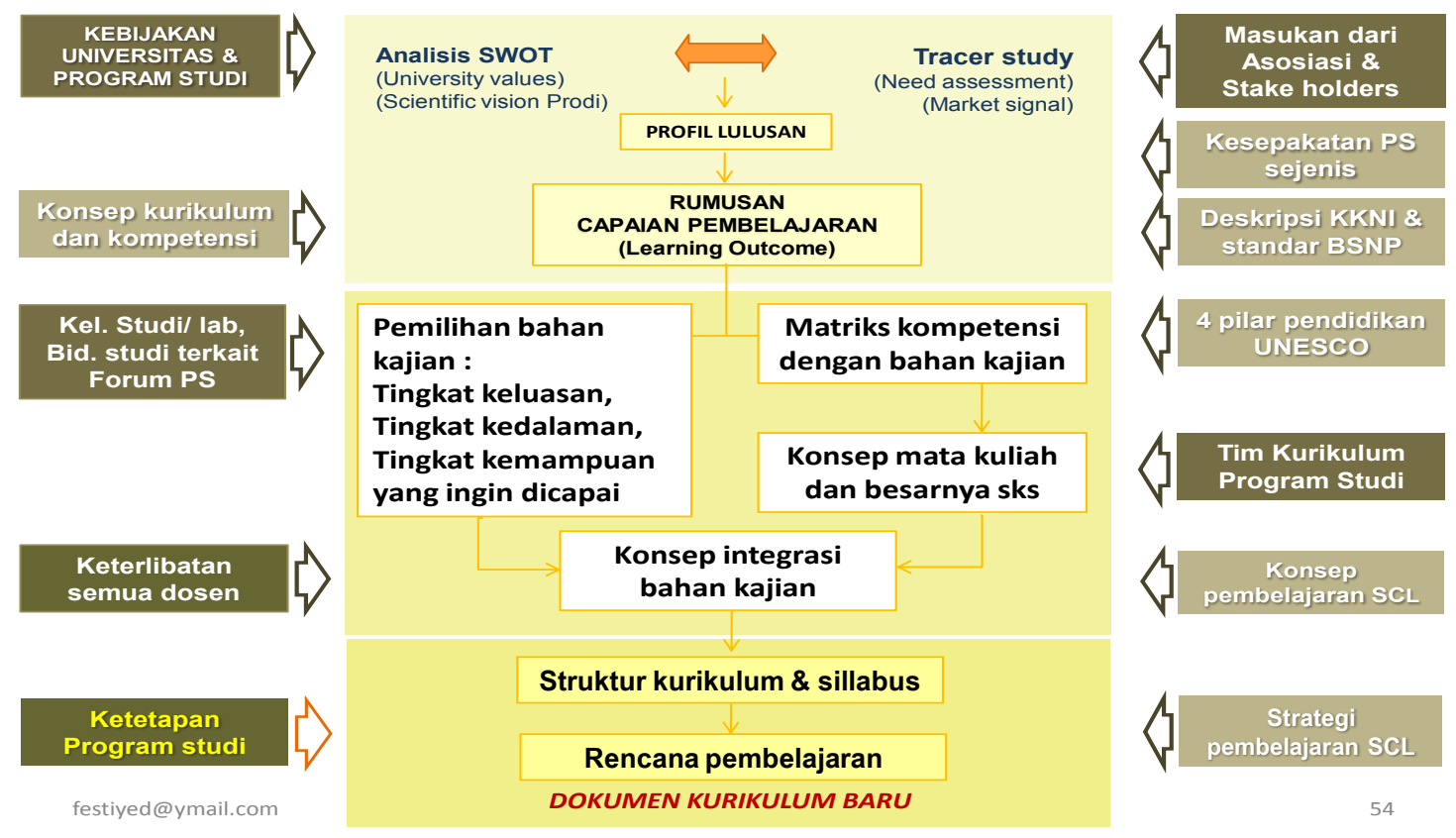

Gambar 2 Tahap Pengembangan Kurikulum Mengacu KKNI (Endrotomo, 2010)

Kerangka Kualifikasi Nasional Indonesia, yang selanjutnya disingkat KKNI, adalah kerangka penjenjangan kualifikasi kompetensi yang dapat menyandingkan, menyetarakan, dan mengintegrasikan antara bidang pendidikan dan bidang pelatihan kerja serta pengalaman kerja dalam rangka pemberian pengakuan kompetensi kerja sesuai dengan struktur pekerjaan di berbagai sektor. KKNI terdiri atas 9 (sembilan) jenjang kualifikasi, dimulai dari jenjang 1 (satu) sebagai jenjang terendah sampai dengan jenjang 9 (sembilan) sebagai jenjang tertinggi. Jenjang 1 sampai dengan jenjang 3 dikelompokkan dalam jabatan operator; Jenjang 4 sampai dengan jenjang 6 dikelompokkan dalam jabatan teknisi atau analis; Jenjang 7 sampai dengan jenjang 9 dikelompokkan dalam jabatan ahli. 


\section{RENCANA KEDEPAN}

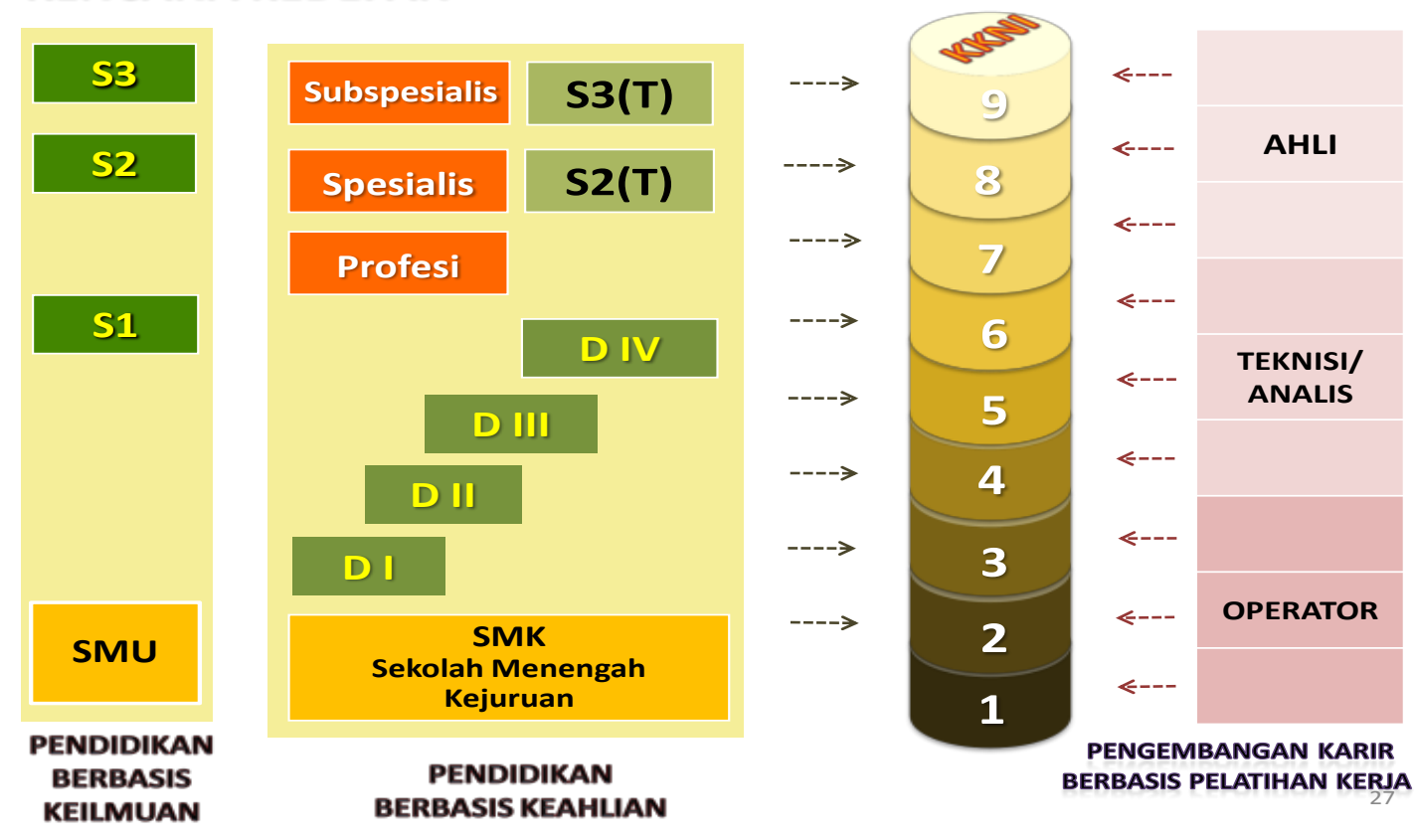

Gambar 3 Kesetaraan Jenjang Pendidikan Mengacu KKNI (Endrotomo, 2010)

Kurikulum ke depan mengacu pada jenjang kualifikasi pada KKNI memiliki kesetaraan dengan capaian pembelajaran yang dihasilkan melalui pendidikan, pelatihan kerja atau pengalaman kerja. Capaian pembelajaran yang diperoleh melalui pendidikan atau pelatihan kerja dinyatakan dalam bentuk sertifikat. Sertifikat berbentuk ijazah dan sertifikat kompetensi. ljazah merupakan bentuk pengakuan atas capaian pembelajaran yang diperoleh melalui pendidikan sedang sertifikat kompetensi merupakan bentuk pengakuan atas capaian pembelajaran yang diperoleh melalui pendidikan atau pelatihan kerja.

Pendidikan menitik beratkan pada usaha memuliakan manusia (educare), ditentukan oleh perubahan mutu kemanusiaannya(optimum menurut kemampuan masingmasing) sedang pelatihan untuk melatih seseorang dalam memberikan kemampuan tertentu lewat cara tertentu dan hasilnya bisa diukur dengan jelas, ditentukan oleh pencapaian kemampuan (ability) dan tanggung jawab kerja (responsibility), menurut standart tertentu. Berdasarkan uraian diatas Istilah yang digunakan untuk menyatakan kemampuan seseorang didalam deskripsi KKNI adalah "capaian pembelajaran" (learning outcome) yang diturunkan dari profil lulusan. Hal ini selain untuk membedakan istilah "kompetensi" yang digunakan oleh dunia profesi untuk menyatakan standar kemampuan dari profesi tersebut dengan istilah "standar kompetensi", juga digunakannya istilah "sertifikat kompetensi"sebagai 
pernyataan kelulusan dari uji kompetensi. Di dalam dunia pendidikan (dalam UU Sisdiknas no 20 tahun 2003) kelulusan jenis pendidikan akademik, vokasi , dan Pendidikan profesi, diberi “ijasah” bukan 'sertifikat kompetensi'.

Untuk jenjang pendidikan dibutuhkan rumusan "learning outcomes" (LO) lulusan prodi tertentu, yang sesuai dengan level KKNI nya, yang akan digunakan sebagai acuan bagi program studi sejenis di seluruh Indonesia. Rumusan tersebut merupakan pernyataan "kemampuan minimal" yang harus dimiliki oleh setiap lulusan program studi tersebut, deskripsinya memenuhi seperti pada Tabel5.

Tabel 5 Parameter dan unsur-unsur deskripsi KKNI

\begin{tabular}{|c|l|l|}
\hline Deskripsi & \multicolumn{1}{|c|}{ Parameter Deskripsi } & \multicolumn{1}{c|}{ Unsur-Unsur Deskripsi } \\
\hline \multirow{2}{*}{$\mathrm{A}$} & \multirow{2}{*}{ Kemampuan di Bidang kerja } & Kemampuan bidang yang terkait \\
\cline { 3 - 3 } & & Metode /cara yang digunakan \\
\cline { 3 - 3 } & & Tingkatan kualitas hasil \\
\cline { 3 - 3 } & & Kondisi /standar proses \\
\hline $\mathrm{B}$ & Lingkup kerja Berdasarkan & \\
& Pengetahuan Yang dikuasai & Lingkup kajian dan cabang ilmu \\
\cline { 3 - 3 } & & $\begin{array}{l}\text { Kemampuan berdasarkan bidang } \\
\text { ilmu }\end{array}$ \\
\hline $\mathrm{C}$ & Kemampuan Manajerial & Lingkup tanggung jawab \\
\cline { 3 - 3 } & & Standar sikap \\
\hline
\end{tabular}

Apabila profil lulusan sudah dirumuskan maka langkah selanjutnya adalah menyusun komponen learning outcomes apa yang harus ada dalam rangka membentuk profil lulusan tersebut?. Learning Outcomes ("Kompetensi") ini dalam KBK PT terdiri dari kompetensi utama/inti, kompetensi penunjang dan kompetensi lainnya. Kompetensi utama ialah kemampuan seseorang untuk menampilkan kinerja yang memadai pada suatu kondisi pekerjaan yang memuaskan. Kompetensi pendukung ialah kemampuan seseorang yang dapat mendukung kompetensi utama, sedangkan kompetensi lainnya ialah kemampuan seseorang yang berbeda dengan kompetensi utama dan pendukung namun membantu meningkatkan kualitas hidup. Kompetensi lainnya boleh tidak ada dalam kurikulum jika memang tidak diperlukan. Namun, yang penting diketahui adalah bahwa semua kompetensi tersebut harus berisi muatan-muatan yang akan menanamkan landasan kepribadian, mingkatkan penguasaan ilmu dan keterampilan, sehingga dapat diprediksi bahwa lulusan akan mampu berkarya dengan sikap dan perilaku menurut tingkat keahlian berdasarkan 
ilmu dan keterampilan yang dikuasai dan mampu meningkatkan pemahaman kaidah berkehidupan bermasyarakat sesuai dengan pilihan keahlian dalam berkarya. Dengan demikian kurikulum berbasis kompetensi tidak saja memberikan peningkatan dalam hard skills melainkan juga soft skills. Artinya ia tidak hanya menguasai ipteks yang baik, tetapi ia juga mampu mengkomunikasikan ilmunya baik dengan kerja mandiri maupun dalam tim melalui cara berfikir kritis, logis dan analitisnya. Apabila ia menjadi pengusaha maka ia akan menjadi pengusaha yang arif, peduli terhadap lingkungan sekeliling dan tidak serakah.

\section{Pengembangan keprofesian berkelanjutan dan Kurikulum 2013 untuk Sekolah Menengah}

Pengembangan keprofesian berkelanjutan (PKB) adalah pengembangan kompetensi Guru yang dilaksanakan sesuai dengan kebutuhan, bertahap dan berkelanjutan untuk meningkatkan profesionalitasnya. Dengan kata lain PKB merupakan pembaruan secara sadar akan pengetahuan dan peningkatan kompetensi guru sepanjang kehidupan kerjanya, PKB dilakukan terus menerus. PKB berkaitan dengan pengembangan diri dalam rangka peningkatan kinerja dan karir guru. Peraturan Menteri Negara Pendayagunaan Aparatur Negara dan Reformasi Birokrasi No.16/2009 No. 16/2009 menyatakan;

- Guru harus berlatar belakang pendidikan S1/D4 dan mempunyai Sertifikat Pendidik

- Guru mempunyai empat jabatan fungsional (Guru Pertama, Guru Muda, Guru Madya, Guru Utama)

- Beban mengajar guru adalah 24 jam - 40 jam tatap muka/minggu atau membimbing 150 konseli/tahun

- Guru dinilai kinerjanya secara teratur (setiap tahun) melalui Penilaian Kinerja Guru (PK Guru)

- Guru wajib mengikuti Pengembangan Keprofesian Berkelanjutan (PKB) setiap tahun

- PKB harus dilaksanakan sejak III/a, dan sejak III/b guru wajib melakukan publikasi ilmiah dan/atau karya inovatif

- Untuk naik dari IV/c ke IV/d guru wajib melakukan presentasi ilmiah

- Peningkatan karir guru ditentukan oleh perolehan angka kredit

- Perlu konversi hasil PKG dan PKB ke angka kredit 
- Perolehan angka kredit dari PKG dan PKB merupakan satu paket

- Perolehan angka kredit setiap tahun ditetapkan oleh Tim Penilai

Tujuan PKB adalah:

1. Memfasiltasi guru untuk mencapai standar kompetensi profesi yang telah ditetapkan.

2. Memfasilitasi guru untuk terus memutakhirkan kompetensi yang menjadi tuntutan ke depan berkaitan dengan profesinya.

3. Memotivasi guru agar memiliki komitmen melaksanakan tugas pokok dan fungsinya sebagai tenaga profesional.

4. Mengangkat citra, harkat, martabat profesi guru, rasa hormat dan bangga kepada penyandang profesi guru.

Tabel 1.Macam dan Jenis Kegiatan PKB

\begin{tabular}{|c|c|c|}
\hline No & Macam PKB & Jenis Kegiatan \\
\hline 1 & Pengembangan Diri & $\begin{array}{l}\text { a) Diklat fungsional } \\
\text { b) Kegiatan kolektif guru }\end{array}$ \\
\hline 2 & Publikasi Ilmiah & $\begin{array}{l}\text { a) Presentasi pada forum ilmiah } \\
\text { b) Publikasi ilmiah atas hasil penelitian atau } \\
\text { gagasan ilmu di bidang pendidikan } \\
\text { formal } \\
\text { c) Publikasi buku pelajaran, buku } \\
\text { pengayaan, dan pedoman guru }\end{array}$ \\
\hline 3 & Karya Inovatif & $\begin{array}{l}\text { a) Menemukan teknologi tepat guna } \\
\text { b) Menemukan/menciptakan karya seni } \\
\text { c) Membuat/memodifikasi alat pelajaran/ } \\
\text { peraga/praktikum } \\
\text { d) Mengikuti pengembangan penyusunan } \\
\text { standar pedoman, soal dan sejenisnya }\end{array}$ \\
\hline
\end{tabular}

Kebutuhan akan orientasi baru dalam pendidikan ini terasa begitu kuat dan nyata dalam berbagai bidang studi, baik dalam bidang studi eksakta maupun ilmuilmu sosial. Para pendidik, praktisi pendidikan dan kita semua, mau tidak mau harus merespon perubahan yang terjadi dengan mengubah paradigma pendidikan. 
Pengembangan kurikulum 2013 untuk sekolah menengah dapat dilihat perbedaan dan persamaan dengan kurikulum sebelumnya pada Tabel 2.

Tabel 2. Perbandingan Kurikulum dari Masa ke Masa

\begin{tabular}{|l|l|l|l|}
\hline No & $\begin{array}{l}\text { Kurikulum .... } \\
1994\end{array}$ & $\begin{array}{l}\text { Kurikulum 2004 } \\
-2006\end{array}$ & Kurikulum 2013 \\
\hline 1 & Basis materi & Basis produk & Basis praksis \\
\hline 2 & $\begin{array}{l}\text { Fokus pada } \\
\text { ranah } \\
\text { pengetahuan }\end{array}$ & $\begin{array}{l}\text { Mapel } \\
\text { berkontribusi } \\
\text { pada kompetensi } \\
\text { tertentu }\end{array}$ & $\begin{array}{l}\text { Mapel berkontribusi pada semua } \\
\text { ranah kompetensi }\end{array}$ \\
\hline 2 & $\begin{array}{l}\text { Produk dan } \\
\text { proses } \\
\text { ditentukan dari } \\
\text { materi }\end{array}$ & $\begin{array}{l}\text { Produk } \\
\text { ditentukan dari } \\
\text { materi, proses } \\
\text { ditentukan } \\
\text { terpisah }\end{array}$ & $\begin{array}{l}\text { Materi dan proses diturunkan dari } \\
\text { produk }\end{array}$ \\
\hline 2 & $\begin{array}{l}\text { Penekanan pada } \\
\text { rencana }\end{array}$ & $\begin{array}{l}\text { Penekanan pada } \\
\text { hasil }\end{array}$ & $\begin{array}{l}\text { Penekanan keselarasan rencana, } \\
\text { kegiatan, hasil }\end{array}$ \\
\hline 3 & $\begin{array}{l}\text { Keseragaman } \\
\text { materi }\end{array}$ & $\begin{array}{l}\text { Keseragaman } \\
\text { hasil } \\
\text { standar } \\
\text { kenteks }\end{array}$ & $\begin{array}{l}\text { Keseragaman materi, proses dan } \\
\text { hasil }\end{array}$ \\
\hline 4 & $\begin{array}{l}\text { Pemantauan } \\
\text { selaksanaan }\end{array}$ & $\begin{array}{l}\text { Penilaian hasil } \\
\text { yang sangat } \\
\text { ketat (harusnya), } \\
\text { mis. UN }\end{array}$ & $\begin{array}{l}\text { Penilaian proses dan hasil secara } \\
\text { utuh }\end{array}$ \\
\hline konteks
\end{tabular}

Untuk indikator keberhasilan dan Perubahan paradigma untuk proses pembelajaran dan penilaian dalam pengembangan kurikulum pada tabel 3 dan Tabel 4 berikut.

Tabel 3 Indikator Keberhasilan Implementasi Kurikulum 2013 


\begin{tabular}{|c|c|c|}
\hline No & $\begin{array}{l}\text { Entitas } \\
\text { Pendidikan }\end{array}$ & Indikator Keberhasilan \\
\hline \multirow[t]{2}{*}{1} & Peserta Didik & Lebih produktif, kreatif, inovatif, afektif \\
\hline & & Lebih senang belajar \\
\hline \multirow[t]{4}{*}{2} & $\begin{array}{l}\text { Pendidik dan } \\
\text { Tenaga } \\
\text { Kependidikan }\end{array}$ & Lebih bergairah dalam melakukan proses pembelajaran \\
\hline & & Lebih mudah dalam memenuhi ketentuan 24 jam per minggu \\
\hline & \multirow{2}{*}{$\begin{array}{l}\text { Manajemen } \\
\text { Satuan } \\
\text { Pendidikan }\end{array}$} & $\begin{array}{l}\text { Lebih mengedepankan layanan pembelajaran termasuk } \\
\text { bimbingan dan penyuluhan }\end{array}$ \\
\hline & & $\begin{array}{l}\text { Terjadinya proses pembelajaran yang lebih variatif di } \\
\text { sekolah }\end{array}$ \\
\hline \multirow[t]{2}{*}{4} & $\begin{array}{l}\text { Negara dan } \\
\text { bangsa }\end{array}$ & Reputasi internasional pendidikannya menjadi lebih baik \\
\hline & & $\begin{array}{l}\text { Memiliki daya saing yang lebih tinggi, sehingga lebih menarik } \\
\text { bagi investor }\end{array}$ \\
\hline \multirow[t]{2}{*}{5} & $\begin{array}{l}\text { Masyarakat } \\
\text { Umum }\end{array}$ & Memperoleh lulusan sekolah yang lebih kompeten \\
\hline & & $\begin{array}{l}\text { Dapat berharap kebutuhan pendidikan akan dipenuhi oleh } \\
\text { sekolah (tidak perlu kursus tambahan) }\end{array}$ \\
\hline
\end{tabular}

Tabel 4. Perubahan paradigma untuk proses pembelajaran dan penilaian

\begin{tabular}{|c|c|c|}
\hline No & Proses & Karakteristik Penguatan \\
\hline \multirow{4}{*}{1} & \multirow{4}{*}{$\begin{array}{l}\text { Pembelaj } \\
\text { aran }\end{array}$} & $\begin{array}{l}\text { Menggunakan pendekatan saintifik melalui mengamati, menanya } \\
\text { mencoba, menalar,.... }\end{array}$ \\
\hline & & $\begin{array}{l}\text { Menggunakan ilmu pengetahuan sebagai penggerak } \\
\text { pembelajaran untuk semua mata pelajaran }\end{array}$ \\
\hline & & $\begin{array}{l}\text { Menuntun siswa untuk mencari tahu, bukan diberi tahu [discovery } \\
\text { learning] }\end{array}$ \\
\hline & & $\begin{array}{l}\text { Menekankan kemampuan berbahasa sebagai alat komunikasi, } \\
\text { pembawa pengetahuan dan berfikir logis, sistematis, dan kreatif }\end{array}$ \\
\hline \multirow{4}{*}{2} & \multirow{4}{*}{ Penilaian } & Mengukur tingkat berfikir siswa mulai dari rendah sampai tinggi \\
\hline & & $\begin{array}{l}\text { Menekankan pada pertanyaan yang mebutuhkan pemikiran } \\
\text { mendalam [bukan sekedar hafalan] }\end{array}$ \\
\hline & & Mengukur proses kerja siswa, bukan hanya hasil kerja siswa \\
\hline & & Menggunakan portofolio pembelajaran siswa \\
\hline
\end{tabular}




\section{DAFTAR BACAAN}

Undang-Undang (UU) nomor 20 tahun 2003 tentang Sistem Pendidikan Nasional,

UU nomor 12 tahun 2012 tetang pendidikan,

Peraturan Pemerintah Nomor 8 tahun 2012 tentang KKNI (Kerangka kualifikasi nasional indonesia).

Festiyed. (2012). Implementasi Model Perangkat Penilaian Berbasis Deskripsi KKNI pada Pembelajaran Fisika FMIPA Universitas Negeri Padang, Laporan Hasil Penelitian . Universitas Negeri Padang

Festiyed. (2005). Pengembangan Kurikulum Fisika FMIPA UNP Beorientasi Kecakapan Hidup (Life Skill), Makalah Seminar Kurikulum, Pasca Sarjana UNP Padang

Popham, W. J. (1995). Classroom Assessment: What Teachers Need to Know. Boston: Allyn and Bacon.

Sumiati,dkk.2008. Metode Pembelajaran. Bandung: CV. Wacana Prima Tilaar, H.A.R. (Ed.). 2004. Paradigma Baru Pendidikan Nasional. Jakarta: Rineka Cipta

Wena.2009. Stategi Pembelajaran Inovatif Kontemporer. Jakarta: Bumi Aksara. http://illahsailah.wordpress.com/ /

Endrotomo(2010) Presentasi seminar dan workshop do UNP 2010

Suryo Subroto (1977). Suwar (2009). Degeng (1998). Longworth (1999)

Gardner, (2003). Beare \& Slaughter (1993) 